\title{
地下水を含む地盤振動の数值解析 \\ NUMERICAL ANALYSIS OF SEISMIC MOTION WITH GROUND WATER EFFECTS
}

\author{
中山昭彦 ${ }^{1} \cdot$ 横山陽子 $^{2} \cdot$ 武本哲也 $^{3}$ \\ Akihiko NAKAYAMA, Yoko YOKOYAMA and Testuya TAKEMOTO \\ '正会員 $\mathrm{PhD}$ 神戸大学 大学院自然科学研究科（广657 神戸市淎区六甲台1-1） \\ 2住宅都市整備公団（广192 東京都八王子市） \\ 3尼崎市役所（广660 尼崎市）
}

\begin{abstract}
Numerical calculation procedure for the motion of ground water during the seismic motion has been developed. It is based on the theory that assumes the ground as a composit body consisting of an elastic porous solid and compressible water filling the pore. One dimensional analysis is first made to validate the computational procedure, then the method is applied to compute the more realistic situation of two-dimensional field with ground plane and the water table. The results show two compression waves and shear waves and details of the ground water movement due to these waves and the interaction of the incident waves and those reflected off ground are seen.
\end{abstract}

Key Words: seismic wave, ground water, finite difference, compression wave, saturated ground

\section{1.はじめに}

地震などの地盤の振動は地下水の存在に大きく影 響される。土粒子骨格のみの地盤の場合、いわゆる 圧縮膨張波の縦波とせん断応力による横波しか存在 しないが、地下水が存在すれば、流体内を高速に伝 播する波が発生したり、間隙水、固体骨格間の相互 作用により複雑な運動になる。Biot ${ }^{11}$ は飽和地盤を 弾性体と流体の複合体と見なし、その間にDarcyの 法則に基づく抵抗力が働くとした理論を提し、その 後実験、数値計算などでその妥当性が確かめられて いる。しかしこれまでになされている解析、計算例 は、一次元柱内での圧縮波の伝播や、数ミリ秒の伝 達時間や数センチの伝達距離などで、実際の地震振 動に応用するには、数 $k m$ に渡る 3 次元振動場、地 下水、地表面の影響などの考慮がなされてなくては ならない。本研究では地表面を上限境界とする半無 限 2 次元場で、地中の任意の点、または領域を強制 振動させた時の、地盤と間隙水の運動を明らかにす る模擬数值計算手法を開発するのが目的である。地 盤は一様等方とするが、地下水面が任意の位置にあ
ることを許す計算法で、実際の地震振動場の解析に 近い条件を想定しているが、間隙水圧により、固体 骨格の特性が変わる、液状化現象等は考慮にいれな い。

Biot $^{1)}$ の理論式は線形であるので幾つかの解析法 による解は可能で、単純な条件で解が得られている

(例えばGarg et al.. ${ }^{2}$, Deresiewicz et al. ${ }^{3)}$, Gajo and Mongiovi $\left.{ }^{4)}\right)$ 。しかしこれらは特殊な場合で、定性 的伝播特性等を調べるには良いが、任意境界などで の実用計算に向いていない。これに対し数値計算は 柔軟性があり、特に有限要素法でいろいろな場合に ついて解が得られている（Zienkiewicz et al. $\left.{ }^{5)}\right)$ 。しかし、Biot ${ }^{1)}$ の式は双曲型で不連続性あ るいは急激な変化を許すので実時間、実空間での数 值積分には注意を要する。このため特性曲線法が適 しているが境界面などのある場合非常に複雑になり 殆ど使われていない。有限差分法はあまり用いられ ていなかったが、近年圧縮性流体の運動方程式を解 くための高解像度法が開発され、衝撃波などの局所 急変で平滑化されることなく、振動を許さず精度良 く安定に解く数值計算スキームが開発されている。 
本研究では予測子・修正子法であるMacCormack法6) を用いた。まず数值計算の妥当性、精度を検証する ため、これまで解析解や数值解の求められている一 次元振動場での計算を行った後、地表面の影響を受 ける 2 次元場での数値計算を行い、地震動の伝播な どの解析など実際の応用の可能性を検討した。

\section{2. 飽和地盤の基礎運動方程式}

$\left(v_{x}^{(s)}, v_{y}^{(s)}\right),\left(v_{x}^{(f)}, v_{y}^{(f)}\right)$ を地盤固体骨格、及び間隙 水の $(x, y)$ 方向の変位速度とすると、Biot ${ }^{1)}$ の理論によれば、固体骨格、間隙水の運動方程式は

$$
\begin{gathered}
\rho^{(s)} \frac{\partial v_{x}^{(s)}}{\partial t}=\frac{\partial \sigma_{x x}}{\partial x}+\frac{\partial \sigma_{x y}}{\partial y}-D\left(v_{x}^{(s)}-v_{x}^{(f)}\right) \\
\rho^{(s)} \frac{\partial v_{y}^{(s)}}{\partial t}=\frac{\partial \sigma_{y x}}{\partial x}+\frac{\partial \sigma_{y y}}{\partial y}-D\left(v_{y}^{(s)}-v_{y}^{(f)}\right)-\rho^{(s)} g \\
\rho^{(f)} \frac{\partial v_{x}^{(f)}}{\partial t}=-\frac{\partial p}{\partial x}+D\left(v_{x}^{(s)}-v_{x}^{(f)}\right) \\
\rho^{(f)} \frac{\partial v_{y}^{(f)}}{\partial t}=-\frac{\partial p}{\partial y}+D\left(v_{y}^{(s)}-v_{y}^{(f)}\right)-\rho^{(f)} g
\end{gathered}
$$

で与えられる。ここで $\rho^{(s)}, \rho^{(f)}$ はそれぞれ地盤単 位体積当りの固体骨格と、間隙水の質量（有効密 度）、 $\sigma_{x x}, \sigma_{x y}, \sigma_{y y}$ は固体骨格に働く応力成分、 $p$ は間隙水の圧力、 $g$ は重力の加速度、 $D$ は固体、 流体の相対速度による摩擦応力係数で、 $\mu$ を流体の 粘性係数、1- $n_{0}$ を有効間隙率、 $k$ を透水係数とす ると

$$
D=\frac{\mu\left(1-n_{o}\right)^{2}}{k}
$$

である。固体に働く応力は、弾性体と流体の複合体 の構成式より、弾性体骨格の变位 $\left(u_{x}^{(s)}, u_{y}^{(s)}\right)$, 流体 の変位 $\left(u_{x}^{()}, u_{y}^{(f)}\right)$ で

$$
\begin{gathered}
\sigma_{x x}=\left(a-2 \mu_{p}\right)\left(\frac{\partial u_{x}^{(s)}}{\partial x}+\frac{\partial u_{y}^{(s)}}{\partial y}\right)+2 \mu_{p} \frac{\partial u_{x}^{(s)}}{\partial x} \\
+c\left(\frac{\partial u_{x}^{(f)}}{\partial x}+\frac{\partial u_{y}^{(f)}}{\partial y}\right) \\
\sigma_{x y}=\mu_{p}\left(\frac{\partial u_{x}^{(s)}}{\partial y}+\frac{\partial u_{y}^{(s)}}{\partial x}\right)
\end{gathered}
$$

$$
\begin{aligned}
\sigma_{y y}=(a & \left.-2 \mu_{p}\right)\left(\frac{\partial u_{x}^{(s)}}{\partial x}+\frac{\partial u_{y}^{(s)}}{\partial y}\right)+2 \mu_{p} \frac{\partial u_{y}^{(s)}}{\partial y} \\
& +c\left(\frac{\partial u_{x}^{(f)}}{\partial x}+\frac{\partial u_{y}^{(f)}}{\partial y}\right)
\end{aligned}
$$

と表わされ、流体圧力は

$$
p=-c\left(\frac{\partial u_{x}^{(s)}}{\partial x}+\frac{\partial u_{y}^{(s)}}{\partial y}\right)-b\left(\frac{\partial u_{x}^{(f)}}{\partial x}+\frac{\partial u_{y}^{(f)}}{\partial y}\right)
$$

で与えられる。ここで $a, \mu_{p}$ は複合体のラーメ定 数で、

$$
\begin{aligned}
& a=n_{o} K_{1}\left(1+b_{1}\right) \\
& b=\left(1-n_{o}-n_{o} b_{2}\right) K_{2} \\
& c=n_{o} K_{1} b_{2}=-n_{o} K_{2} b_{1}
\end{aligned}
$$

である。 $K_{1}, K_{2}$ は間隙のない固体と流体の弾性係 数で、

$$
\begin{aligned}
& a_{1}=a / n_{o} K_{1}-1 \\
& b_{1}=a_{1}\left(1-n_{o}\right)\left[1-n_{o}-n_{o}\left(K_{1} / K_{2}\right) a_{1}\right]^{-1}
\end{aligned}
$$

である。これらの基礎式とその解の持つ意味は例え ば Corapciouglu ${ }^{7)}$ 等に詳しく解説されている。ま ず 2 種類の膨張圧縮による疎密波（いわゆる縱波） が存在し、一つは流体を通して伝播するもので、他 の一つは弾性体を通して伝播するものである。この 二つの波は固体と流体の運動によって生ずる連性効 果を受けるのみならず、その系をなす固体と流体の 合成の影響もうける。いわゆる横波である回転波は 2 次元または 3 次元振動場で発生し得るが、だた一 つのみである。これは、弾性体には発生するが Darcy 則に従う流体には発生しないせん断力による もので、その伝播は固体、流体の連性運動に影響を

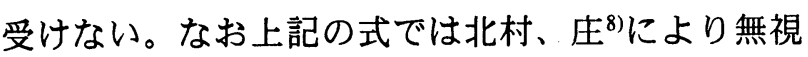
しても良いとされる固体と流体の慣性力の相互作用 による質量連性は無視してある。

初期条件には変位と速度が与えられているとす る。境界条件は固定境界で全ての変位がゼロ、自由 境界 $y=$ Const. では固体骨格及び間隙水の境界面に 㗢く応力がゼロであるので

$$
\begin{gathered}
\sigma_{x y}=\mu_{p}\left(\frac{\partial u_{x}^{(s)}}{\partial y}+\frac{\partial u_{y}^{(s)}}{\partial x}\right)=0 \\
\sigma_{y y}=\left(a-2 \mu_{p}\right)\left(\frac{\partial u_{x}^{(s)}}{\partial x}+\frac{\partial u_{y}^{(s)}}{\partial y}\right)+2 \mu_{p} \frac{\partial u_{y}^{(s)}}{\partial y} \\
+c\left(\frac{\partial u_{x}^{(f)}}{\partial x}+\frac{\partial u_{y}^{(f)}}{\partial y}\right)=0
\end{gathered}
$$




$$
\begin{gathered}
p=-c\left(\frac{\partial u_{x}^{(s)}}{\partial x}+\frac{\partial u_{y}^{(s)}}{\partial y}\right)-b\left(\frac{\partial u_{x}^{(f)}}{\partial x}+\frac{\partial u_{y}^{(f)}}{\partial y}\right)=0 \\
\frac{\partial u_{x}^{(f)}}{\partial y}+\frac{\partial u_{y}^{(f)}}{\partial x}=0
\end{gathered}
$$

である。式(15)、は相互作用の項が小さい時、式 (3),(4)の解は自動的に満たしている。式(14)を(12) に代入すると固体骨格の変位 $u_{x}{ }^{(s)}, u_{y}{ }^{(s)}$ のみの式

$$
\begin{gathered}
\left(a-2 \mu_{p}-\frac{c^{2}}{b}\right)\left(\frac{\partial u_{x}^{(s)}}{\partial x}+\frac{\partial u_{y}^{(s)}}{\partial y}\right)+2 \mu_{p} \frac{\partial u_{y}^{(s)}}{\partial y}=0 \\
\frac{\partial u_{x}^{(s)}}{\partial y}+\frac{\partial u_{y}^{(s)}}{\partial x}=0
\end{gathered}
$$

に変換できる。さらにこれらより $x, y$ についての 偏微分をとり $u_{y}^{(s)}$ を消去すれば $u_{x}^{(s)}$ のみの式、あ るいは $u_{x}^{(s)}$ を消去すれば $u_{y}^{(s)}$ のみの式を得る事が 出来る。 $u_{y}^{(f)}, u_{y}^{(f)}$ はこれらが求まればそれを用いて 表す事が出来る。

\section{3. 数值計算法}

上に示した方程式を等間隔直交格子上 $(x$ 方向の 間隔 $\Delta x 、 y$ 方向の間隔 $\Delta y$ ) で、 2 次精度の差分法で ある MacCormack 法にて離散化する。 $v_{x}^{(s)}, v_{y}^{(s)}$, $v_{x}^{()}, v_{y}^{(f)}$ のいずれかを $v(x, y, t)$ とし、その $x=x_{i}=i \Delta x, y=y_{j}=j \Delta y, t=t^{n}=n \Delta t$ での值を $v_{i j}{ }^{n}$ とする 之、第一段階の予測子 $v_{i j}{ }^{*}$ は

$$
v_{i j}^{*}=v_{i j}^{n}+\frac{\Delta t}{\rho} F_{i+1 / 2, j+1 / 2}^{n}
$$

で与えられ、修正子 $v_{i j}{ }^{n+1}$ は

$$
v_{i j}^{n+1}=\frac{1}{2}\left(v_{i j}^{n}+v_{i j}^{*}\right)+\frac{\Delta t}{2 \rho} F_{i-1 / 2, j-1 / 2}^{*}
$$

で与えられる。ここで $F^{n}{ }_{i+1 / 2, j+1 / 2}$ は式(1)-(4)の右辺 の離散化值で、例えば $v_{\mathrm{x}}^{(s)}$ についての式(1)の場合

$$
\begin{aligned}
F_{i+1 / 2, j+1 / 2}^{n} & =\frac{\sigma_{x x i+1, j}^{n}-\sigma_{x x i j}^{n}}{\Delta x}+\frac{\sigma_{x y i j+1}^{n}-\sigma_{x y i j}^{n}}{\Delta y} \\
& -D\left(\frac{v_{x i j}^{(s) n}+v_{x i+1, j}^{(s) n}}{2}-\frac{v_{x i j}^{(\rho) n}+v_{x i j}^{(\rho) n}}{2}\right)
\end{aligned}
$$

で、 $F_{i-1 / 2, j-1 / 2}^{*}$ は

$$
\begin{aligned}
& F_{i-1 / 2, j-1 / 2}^{*}= \frac{\sigma_{x x i j}^{*}-\sigma_{x x i-1, j}^{*}}{\Delta x}+\frac{\sigma_{x y i j}^{*}-\sigma_{x y i j-1}^{*}}{\Delta y}- \\
& D\left(\frac{v_{x i j}^{(s) *}+v_{x i-1, j-1}^{(s) *}}{2}-\frac{v_{x i j}^{(f) *}+v_{x i-1, j-1}^{(s) *}}{2}\right)
\end{aligned}
$$

$$
u_{x i j}^{*}=u_{x i j}^{n}+\Delta t v_{x i j}^{n}
$$

より求めた応力である。

固定境界での境界值はこれらの式のに組み込まれ るが、地表面境界では式(14),(15)を離散化し、境界 面上の $u_{x}^{(s)}$ 、及び $u_{y}^{(s)}$ について解いた上で、 $u_{x}^{\left({ }^{()}\right.}$, $u_{y}^{(\text {) }}$ 求める。その際領域内部点での值が既に計算 されているので境界上の点の值のみの連立方程式に 書く事が出来る。

\section{1 次元振動場での検証}

上記の運動方程式は当然 $y$ 方向に変化のない 1 次元場に適応出来る。Garg et al. ${ }^{2)}$ は一次元柱状地 盤の一端が $t=0$ で瞬間的に一定の速度で動きだす 時の振動の伝播を解析しているので、同じ条件で本 計算法を適応し検証する。Garg et al. の用いた各 定数の数值は

$$
\begin{aligned}
& n_{0}=0.82 \\
& \rho_{0}^{(s)}=2.18 \mathrm{~g} / \mathrm{cm}^{3}, \quad \rho_{0}^{(A)}=0.18 \mathrm{~g} / \mathrm{cm}^{3} \\
& K_{1}=0.36 \times 10^{12} \mathrm{dyn} / \mathrm{cm}^{2}, \quad K_{2}=0.22 \times 10^{11} \mathrm{dyn} / \mathrm{cm}^{2} \\
& a=K=0.118 \times 10^{12} \mathrm{dyn} / \mathrm{cm}^{2}, \quad \mu_{p}=0.99 \times 10^{11} \mathrm{dyn} / \mathrm{cm}^{2}
\end{aligned}
$$

で、 $D$ の值は $0.219 \times 10^{2}, 0.219 \times 10^{4}, 0.219 \times 10^{8}$ $\mathrm{g} / \mathrm{cm}^{3} \mathrm{sec}$ の 3 ケースについて計算している。固体 と流体の速度の時間変動の結果を出している。本計 算では、そのうち粘性抵抗による連性効果の低い $D=0.219 \times 10^{2} \mathrm{~g} / \mathrm{cm}^{3} \mathrm{sec}$ と連性効果のある $D=0.219 \times 10^{4} \mathrm{~g} / \mathrm{cm}^{3} \mathrm{sec}$ とについて詳しく比較した。

これらは透水係数 $k=10^{-5}$ 及び $10^{-8} \mathrm{~cm} / \mathrm{sec}$ に相当 し、砂岩から頁岩などの透水性の低い岩に相当す る。1 次元では、いわゆる縦波である膨張圧縮波の みしか存在しないが、間隙水を伝わる第 1 種波と固 体粒子を伝わる第 2 種波の伝播状況の計算結果を比 べる事が可能である。

図-1と図-2に $D=0.219 \times 10^{2} \mathrm{~g} / \mathrm{cm}^{3} \mathrm{sec}$ の場合の間隙 水の速度と固体骨格の $x=10 \mathrm{~cm}$ での值の本計算結 果と Garg et al. ${ }^{2)}$ の結果を共に示す。Garg et al. の解析解は $D=0$ の極限の近似で、固体、流体の相 互作用がなく波形は段階的変化しか表せない。 Garg et al. の数值計算結果と本計算結果は良く一 致しており、本計算の妥当性を示唆している。

図-3と図-4は $D=0.219 \times 10^{4} \mathrm{~g} / \mathrm{cm}^{3} \mathrm{sec}$ の場合の同様 の比較図である。Garg et al. 及び本数值計算結果 はラプラス数值逆変換に表れている波先端の急激変 化は正確に捉えられていないものの、第 1 種、第 2 種波の間の緩増加などの特性はよく再現している。 


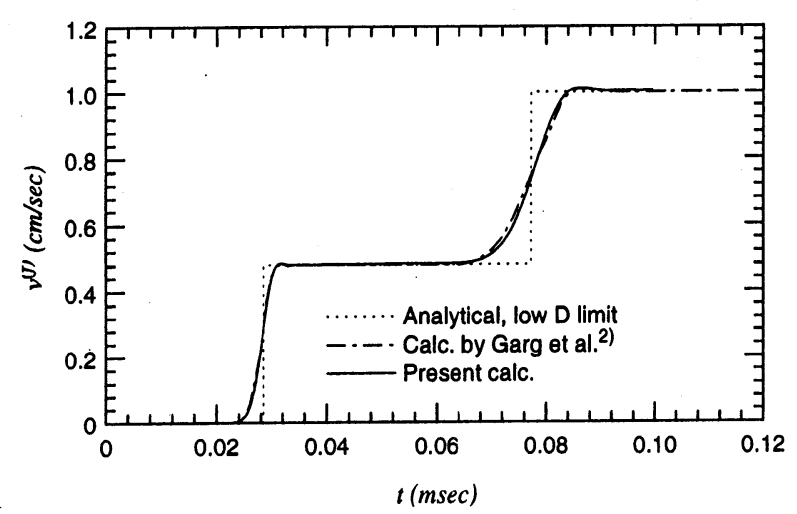

図-1 $x=10 \mathrm{~cm}$ での間隙水の速度, $D=0.219 \times 10^{2} \mathrm{~g} / \mathrm{cm}^{3} \mathrm{sec}$.

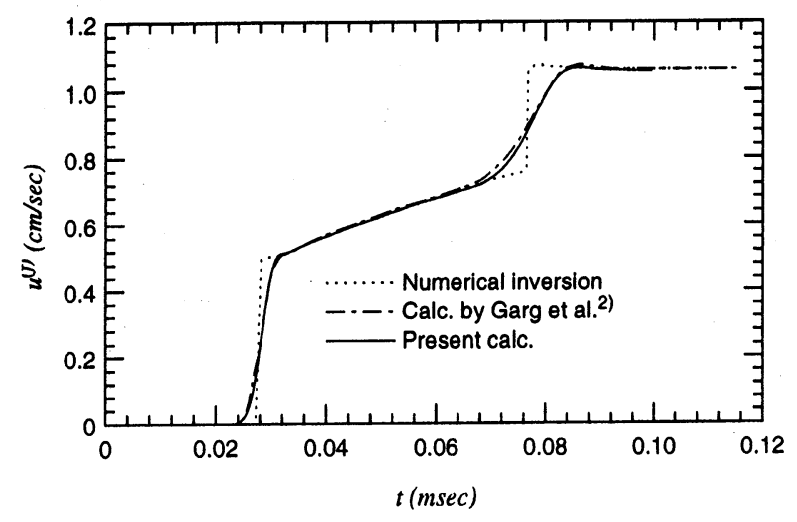

図-3 $x=10 \mathrm{~cm}$ での間隙水の速度, $D=0.219 \times 10^{4} \mathrm{~g} / \mathrm{cm}^{3} \mathrm{sec}$.

\section{2 位次元場での振動伝播}

\section{(1) 1 計算領域と計算ヶース}

図-7は計算領域と震源と位置を示す。震源の深さ を $H=1000 m$ とし、計算領域は $4 H<x<4 H,-5 H<y<0$ の長方形にとってある。左右の境界 $(x= \pm L= \pm 4 H)$ 及び下端の境界 $(y=-5 H)$ は固定とし、 $y=0$ は地表 面とした。計算領域は $200 \times 125$ の一様な間隔の直 交格子で分割した。震源では単一 1 周期余弦波パル スの強制振動

$$
\begin{array}{rlr}
v_{x}^{(s)}(0,0, t) & =v_{x}^{(f)}(0,0, t) \\
& =A\left[\sin \left(2 \pi \frac{t}{t_{p}}-\frac{\pi}{2}\right)+1\right], 0<t<t_{p} \\
v_{x}^{(s)}(0,0, t) & =v_{x}^{(f)}(0,0, t)=0, \quad t_{p}<t \\
v_{y}^{(s)}(0,0, t) & =v_{y}^{(f)}(0,0, t)=0
\end{array}
$$

を与えた。周期 $t_{p}=0.1 \mathrm{sec}$ で振幅は $A=1 \mathrm{~cm} / \mathrm{sec}$ と した。

\section{(2) 計算結果}

図-6に固体骨格の変位を、変形した格子で示し てある。図-7は変位速度べクトルの計算結果で、上 からそれぞれ $t=0.25,0.4,0.6,1.0 \mathrm{sec}$ の結果であ る. $t=0.6,1.0 \mathrm{sec}$ の速度べクトルのスケールは $t=0.25,0.4 \mathrm{sec}$ の倍にとってある。図-8 は間隙水の

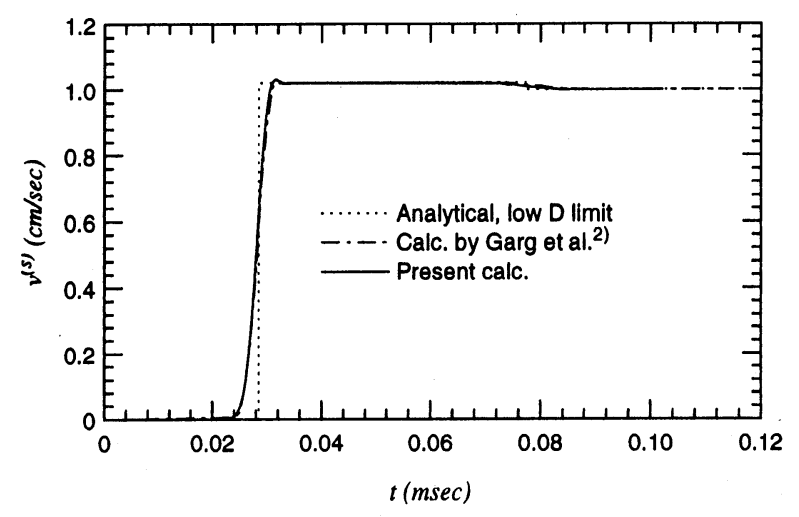

図-2 $x=10 \mathrm{~cm}$ での固体骨格の速度, $D=0.219 \times 10^{2} \mathrm{~g} / \mathrm{cm}^{3} \mathrm{sec}$.

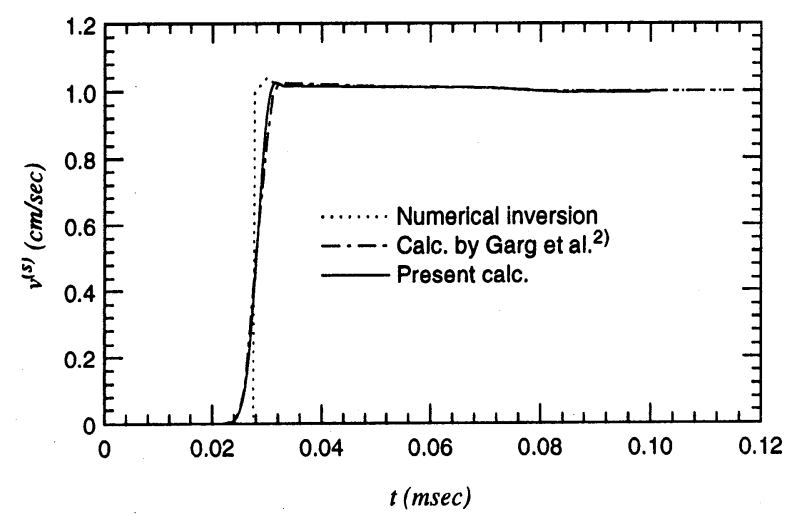

図-4 $x=10 \mathrm{~cm}$ での固体骨格の速度, $D=0.219 \times 10^{4} \mathrm{~g} / \mathrm{cm}^{3} \mathrm{sec}$.

変位速度、図-9は間䏚水の圧力の時間変化を等力線 で示す。何れの場合も図を見易くするため、計算格 子の半数の位置のみプロットしてある。固体骨格の 振動には 2 つ波が見え、それらが地表面に到達す ると反射、屈折したものと元の波と干渉し複雑な動 きになっている。間隙水の方も 2 つ波があるが第 2 波の後複雑な動きが見られる。これらの 2 つの波の うちの伝播速度の速い方は固体骨格と間隙水の伝播 速度が一致している。双方とも動きは伝播の方向と 一致しているが、振幅は震源の動きである水平方向 が最も大きく、その直角方向である震源の上下方向 では殆ど動きが無い。従ってこれは縦波で、1 次元 の時の間隙水を伝わる第 1 種疎密波とその連性効果 と考えられる。第 2 波の方は固体骨格の方に強く見

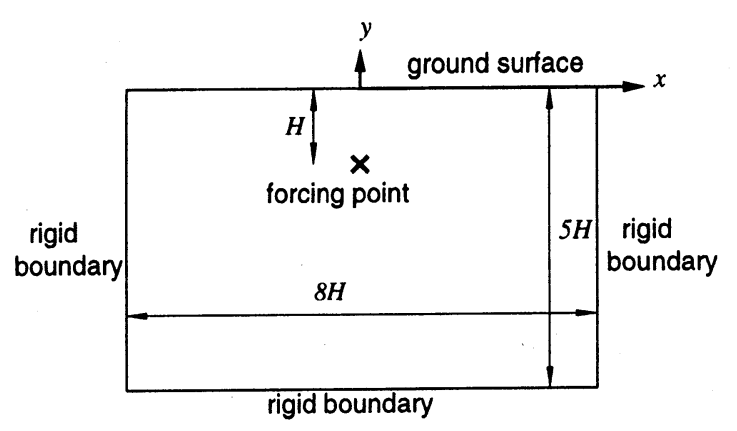

图-5 2 次元計算領域 
(a) $t=0.25 \mathrm{sec}$

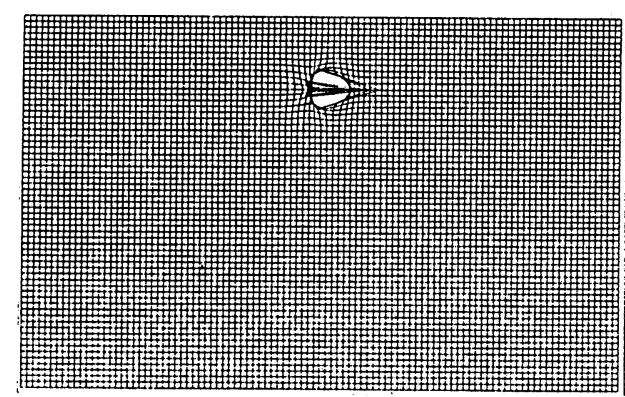

(b) $t=0.40 \mathrm{sec}$

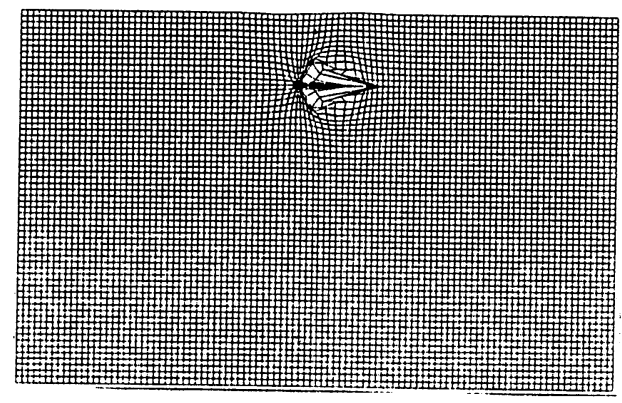

(c) $t=0.60 \mathrm{sec}$

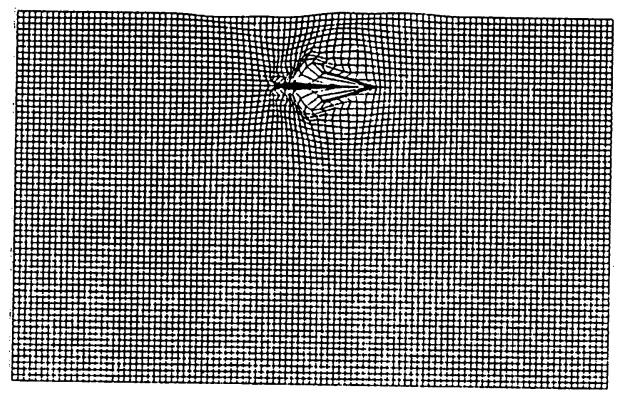

(d) $t=1.0 \mathrm{sec}$

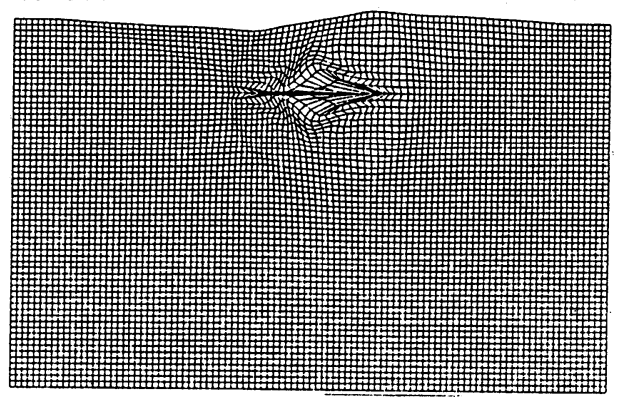

図-6 固体骨格の变位

られ、間隙水の方の伝播速度はさらに遅い。固体骨 格を伝わる第 2 波では、震源の動きである水平方向 の動きが主で、振幅は動きの直角方向である上下方 向で最も大きい。これは膨張圧縮波のみならずせん 断成分も含まれていると見られる。第 2 波の通った 後の間隙水の複雑な動きは固体のせん断運動の摩擦 による連性効果と見られる。

\section{6. おわりに}

地表面を有する半無限 2 次元飽和地盤内の地下水 の運動を Biot の理論に基づき高解像差分法 MacCormack法を用い数值解析した。計算例は地表 (a) $t=0.25 \mathrm{sec}$

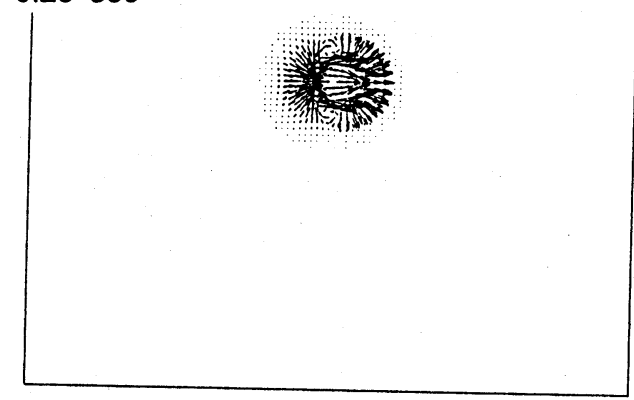

(b) $t=0.40 \mathrm{sec}$

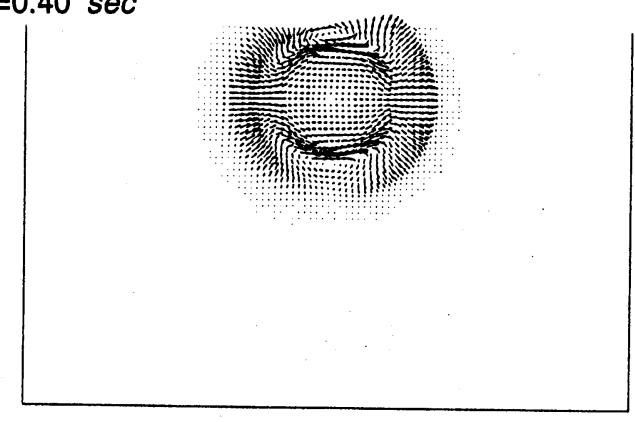

(c) $t=0.60 \mathrm{sec}$

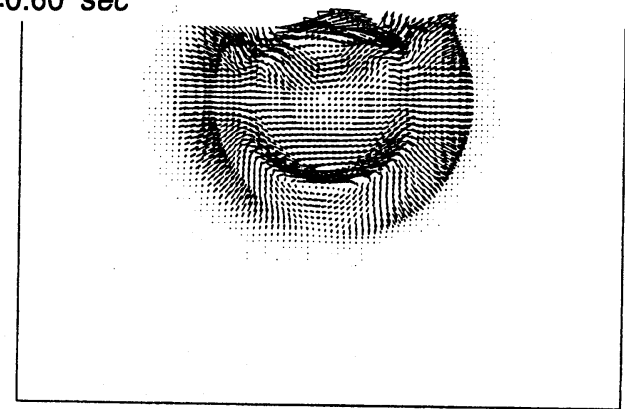

(d) $t=1.00 \mathrm{sec}$

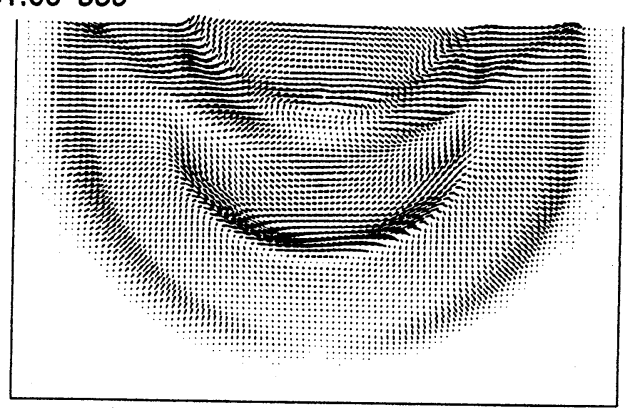

図-7 固体骨格の变位速度ベクトル

下の震源点でパルス状一方向振動速度を強制的に与 えた。2 種の疎密波の発生が確かめられ、これらの 伝播速度は地表面に到達するまでは振動の方向、伝 播の方向に因らずほぼ一定である事が分かった。間 隙水を伝わる第 1 種波は圧縮波であるので振動方向 に最も大きく振動方向に直角の方向ではほぼゼロに なっている。第 2 種波は膨張圧縮による縦波と、せ ん断による横波両方の成分が混在し同じ速度で伝播 する。地表面の影響は 2 種の圧縮波とせん断波によ り動いた地表水面が重力により振動するような動き になっている。本計算法は一般的な境界のある実用 計算に応用出来るであろう。 
(a) $t=0.25 \mathrm{sec}$

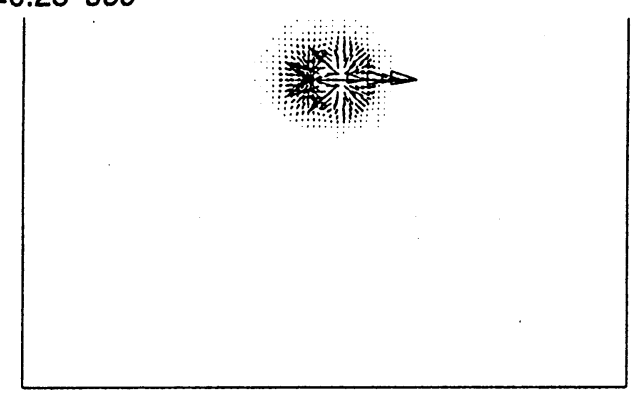

(b) $t=0.40 \mathrm{sec}$

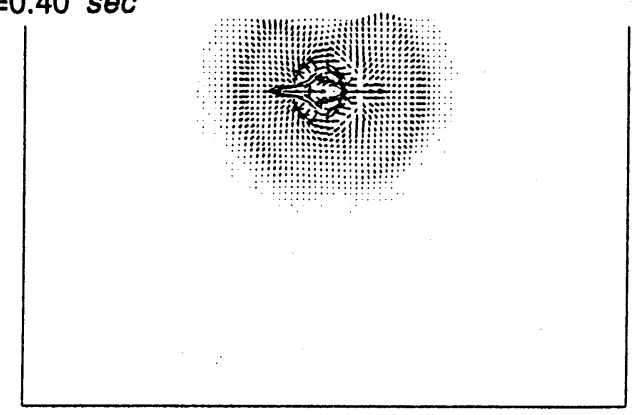

(c) $t=0.60 \mathrm{sec}$

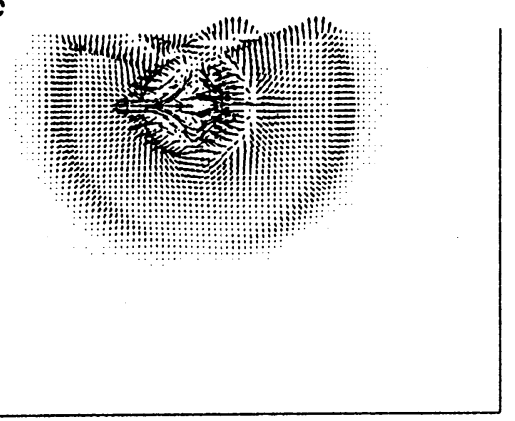

(d) $t=1.0 \mathrm{sec}$

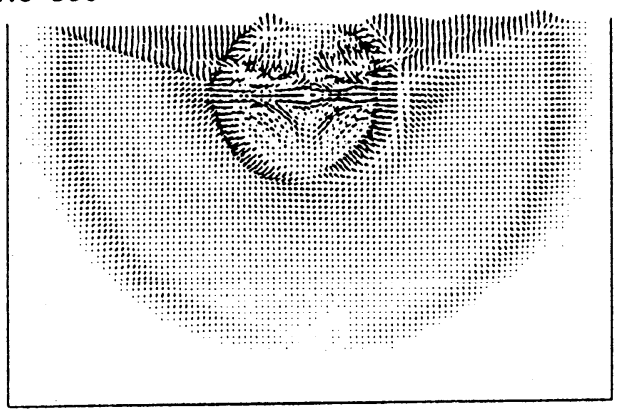

図-8 間隙水の变位速度ベクトル

\section{参考文献}

1) Biot, M.A.:Theory of propagaion of elastic waves in a fluid-saturated porous solid. I. Low-frequency range, J. Acoustical Society of America, Vol.28, No.2, 1956.

2) Garg, S.K., Adnan, H. Nayfeh, H. and Good, A.J.: Compressional waves in fluid-saturated elastic porous media, J. Applied Physics, Vol. 45, No.5, 1974.

3) Deresiewicz, H. and Levy, A.:The effects of boundaries on wave propagation in a liquid-filled porous solid, Bull. Seism. Soc. Am. Vol. 57, pp. 381391, 1967.

4) Gajo, A. and Mongiovi, L.:Analytical Solution for the Transient Response of Saturated Linear Elastic Media, Int. J. for Numer. and Anal. Methods Geomech., Vol. (a) $t=0.25 \mathrm{sec}$

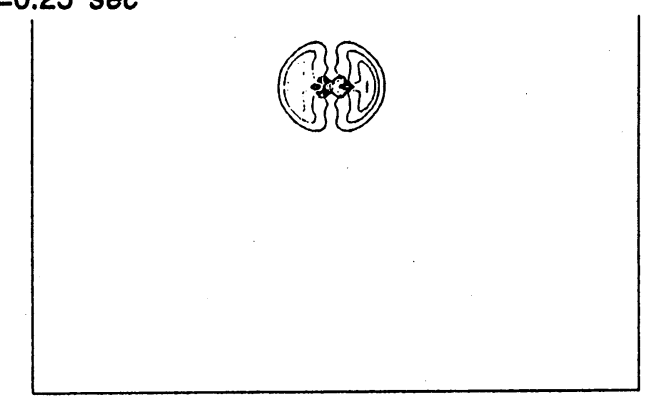

(b) $t=0.40 \mathrm{sec}$

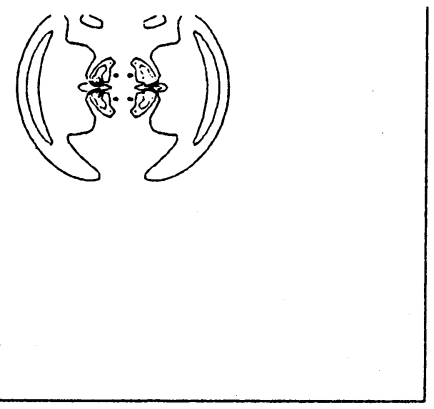

(c) $t=0.60 \mathrm{sec}$

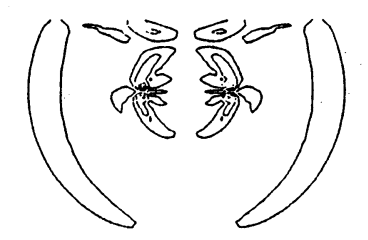

(d) $t=1.0 \mathrm{sec}$

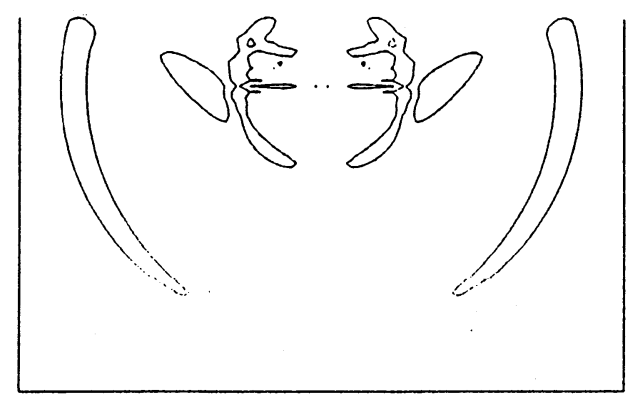

图-9 间隙水圧、等圧線间阽, $\Delta p=1000 P a$

19, pp. 399-413, 1995.

5) Zienkiewicz, O.C. ans Shiomi, T.:Dynamic behaviour of saturated porous media. Int. J. Num. Analy. Meth. Geomech. Vol.8, pp. 71-96, 1984.

6) Hoffman, K.A.:Computational Fluid Dynamics for Engineers. Eng. Education System, Austin, 1989.

7) Corapcioglu, M. Y.:Wave Propagation in Porous Media - A review, Transport Processes in Porous Media. pp. 375-422, Kluwer Academic Pub., 1993.

8）北村泰寿、庄健介：Biotの理論に基づく半無限多孔質 飽和弾性体の表面加振解、神戸大学工学部土地造成 工学研究施設報告、第6号、pp. 91-106, 1988.

(1997.9.30受付) 